\title{
ON-BOARD INFORMATION RESTORING METHOD IN CASE OF FAILURE OF ONE OF THE SENSORS OF THE AIRCRAFT ENGINE TV3-117 BASED ON NEURAL NETWORK TECHNOLOGIES
}

\section{S. Vladov, K. Kotliarov, S. Hrybanova, O. Husarova, L. Chyzhova}

Kremenchuk Flight College of Kharkiv National University of Internal Affairs

\section{vul. Peremogy, 17/6, Kremenchuk, 39605, Ukraine. E-mail: ser26101968@ gmail.com}

Purpose. The work is dedicated to solving one of the key problems solved on board an aircraft, is to identify parametric sensor failures (degradation of their characteristics), by developing an on-board method for recovering information when one of the sensors of TV3-117 aircraft engine fails based on neural network technologies, which will ensure fault tolerance measuring channels of TV3-117 aircraft engine control system. Methodology. The work is based on the methods of probability theory and mathematical statistics, neuroinformatics, information systems theory and data processing. Two neural network architectures are used in the work: a perceptron-type neural network and an autoassociative neural network with the property of compression and subsequent information recovery. Results. A method was developed for determining the optimal structure of a neural network, which consists in determining the neural network architecture, choosing the optimal algorithm for finding weights of neurons and teaching a neural network, analyzing the effectiveness of various neural network training algorithms, determining the structure of a neural network, which consists in finding the minimum error of neural network training depending on the number of neurons in the hidden layer, as well as in the analysis of the effectiveness of the results. It is shown that the implementation of the neural network multimode model of TV3-117 aircraft engine provides a decrease in the error in calculating its thermogasdynamic parameters by 3,7...8,6 times compared with the piecewise-linear model of the aircraft engine TV3117 and 1,5 and 3,5 times compared to the 9th order polynomial model. Information recovery in case of sensor failure using an auto-associative neural network provides a data recovery error of not more than $0,38 \%$ in the case of single failures and not more than $0,54 \%$ in the case of double failures. Originality. The scientific novelty of the results obtained is as follows: For the first time, a method was developed for determining the optimal structure of a neural network, which made it possible to solve the problem of identifying a model of an aircraft engine, the TV3-117, in onboard conditions with minimal errors. The method of identifying the technical condition of the TV3-117 aircraft engine in onboard conditions, which differs from the existing ones due to the use of neural network technologies, makes it possible to increase the reliability of monitoring and diagnostics of the technical condition of the TV3-117 aircraft engine under its flight conditions. Practical value. Neural network algorithms for recovering information in the event of failure of standard sensors as part of the on-board system for monitoring and diagnosing the technical condition of TV3117 aircraft engine have been developed, based on the use of auto-associative neural networks, the use of which allows to restore lost information with real accuracy in real time, the use of which allows to improve the quality and effectiveness of decisions about the technical condition of TV3-117 aircraft engine. References 13, table 4, figure 6.

Key words: aircraft engine, neural network, microprocessor, neuroprocessor, recovery.

\section{БОРТОВИЙ МЕТОД ВІДНОВЛЕННЯ ІНФОРМАЦІЇ ПРИ ВІДМОВІ ОДНОГО $З$ ДАТЧИКІВ АВІАЦІЙНОГО ДВИГУНА ТВЗ-117 НА ОСНОВЕ НЕЙРОМЕРЕЖЕВИХ ТЕХНОЛОГІЙ}

\section{С. І. Владов, К. Г. Котляров, С. А. Грибанова, О. В. Гусарова, Л. І. Чижова}

Кременчуцький льотний коледж Харківського національного університету внутрішніх справ

вул. Перемоги, 17/6, м. Кременчук, 39605, Україна. E-mail: ser26101968@gmail.com

Вирішено одну з ключових проблем, що виникають на борту літального апарату, - виявлення параметричних відмов датчиків, а саме, погіршення їх характеристик, шляхом розробки бортового методу відновлення інформації, коли один із датчиків авіаційного двигуна ТВ3-117 виходить 3 ладу, на основі нейромережевих технологій. Це дозволить забезпечити відмовостійкість вимірювальних каналів системи управління авіаційного двигуна ТВ3-117. Для реалізації поставлених у роботі задач застовуються методи теорії ймовірностей та математичної статистики, нейроінформатики, теорії інформаційних систем та обробки даних. У роботі використовуються дві архітектури нейронної мережі: нейронна мережа типу перцептрон та автоасоціативна нейронна мережа з властивістю стиснення та подальшого відновлення інформації. Розроблено метод визначення оптимальної структури нейронної мережі, який полягає у визначенні архітектури нейронної мережі, виборі оптимального алгоритму пошуку ваг нейронів та навчанні нейронної мережі, аналізі ефективності різних алгоритмів навчання нейронної мережі, визначенні структури нейронної мережі, тобто знаходження мінімальної похибки навчання нейронної мережі залежно від кількості нейронів у прихованому шарі, а також в аналізі ефективності результатів. Показано, що реалізація багаторежимної нейромережевої моделі авіаційного двигуна ТВ3-117 забезпечує зменшення похибки в обчисленні його термогазодинамічних параметрів у $3,7 \ldots 8,6$ разів порівняно 3 кусково-лінійною моделлю авіаційного двигуна ТВ3-117 і в 1,5 і 3,5 рази порівняно 3 поліноміальною моделлю дев'ятого порядку. Відновлення інформації у разі відмови датчика за допомогою автоасоціативної нейронної мережі забезпечує похибку відновлення даних не більше 0,38 \% у випадку одиничних відмов і не більше $0,54 \%$ - для подвійних відмов. Розроблено алгоритми нейронної мережі для відновлення інформації у разі виходу 3 ладу стандартних датчиків як частини бортової системи моніторингу та діагностики технічного стану авіаційного двигуна ТВ3-117 на основі використання автоасоціативних нейронних мереж, застосування яких дозволяє відновити втрачену інформацію з реальною точністю в режимі реального часу та підвищити якість і ефективність рішень про технічний стан авіадвигуна TV3-117.

Ключові слова: авіаційний двигун, нейронна мережа, мікропроцесор, нейропроцесор, відновлення. 
PROBLEM STATEMENT. The development of modern aircraft engines (including TV3-117) requires more qualitative and quick troubleshooting. For this it is necessary to improve continuously the systems for monitoring and diagnosing such engines. The functioning of such systems under conditions of uncertainty factors combined with the high complexity of the processes occurring in the engine makes it appropriate to use intelligent methods to solve problems of monitoring and diagnosing aircraft engines, along with the classical ones.

Analysis of work in the field of building on-board monitoring and diagnostics systems (BMDS) of modern aircraft engines indicates that during their development there was a steady trend towards intellectualization and the transition from passive control to active, allowing not only to localize failures, but also, if possible, to eliminate them [1-3]. Thus, BMDS are gradually distinguished into independent systems with high complexity, multiprocessing, capable of solving complex problems with high quality and efficiency in a real-time pace. It is worth noting that modern BMDS interact with aircraft engine control systems, allowing the latter to smoothly and timely act on actuators, on the one hand, to improve the quality of control of the aircraft engine and its subsystems, and on the other, to increase engine reliability. However, the presences of uncertainties, as well as the need to make operational decisions in real time [4], create additional problems in the process of monitoring and diagnostics within the framework of BMDS. The analysis of modern BMDS shows that the range of tasks solved by them is continuously growing. This is due to the continuous improvement of the aircraft engine itself and, as a result, the functions it performs, as well as a corresponding increase in the number of monitored and diagnosable parameters on board the aircraft.

In [5] described BMDS for an aircraft engine TV3117, which solves a wide range of tasks associated with the assessment of the residual life of the engine and the control of its parameters. In the process of solving the engine resource development problem, the tasks of forecasting (short-term) the current state of the engine and trend analysis of its parameters are solved. With a large variety of problems BMDS to be solved [5], there are certain difficulties:

- limited computing resources (amount of RAM, speed, accuracy of the results);

- the difficulty of formalizing the classical algorithms for monitoring and diagnostics and, as a result, their practical implementation;

- the need to implement the above algorithms in a low-level language (assembler);

- difficulties in recovering information in case of sensor failure.

Under these conditions, the use of neural network technologies is very promising. This paper discusses the features of the use of neural network technologies as a part of BMDS using the example of solving the last of the above tasks associated with the use of available analytical redundancy in measuring the parameters of the TB3-117 aircraft engine for reconstructing signals in case of sensor failures.
MATERIAL AND RESULTS. One of the key tasks solved on board the aircraft is the identification of parametric sensor failures (degradation of their characteristics). In this case, the method of majority control (fig. 1) [6] can be used, as a rule. The essence of the majority control method is that if among the S1 or S2 sensors (measuring, for example, air pressure behind the compressor) (fig. 1), one of them has a different characteristic from the reference one, then the introduction of an additional measurement channel in the form of a mathematical model (MM) allows to calculate the average value of this measurement (median) and thereby recover the information lost from the sensor.

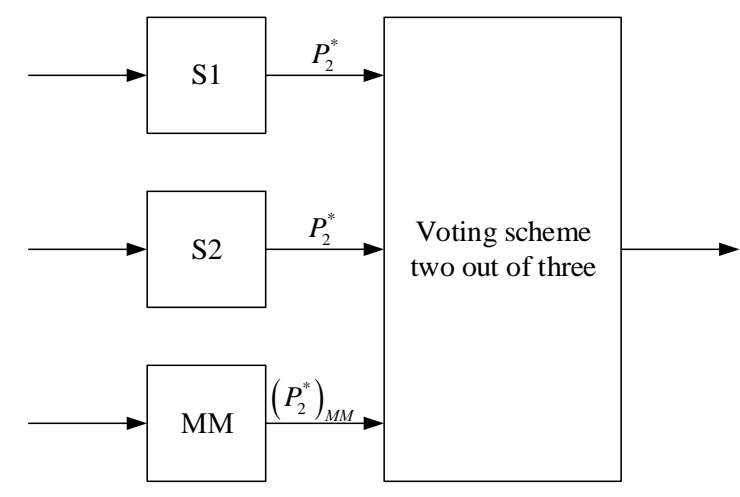

Figure 1 - Implementation of majority control

In this paper, it is proposed to use its neural network model, obtained in the process of solving the identification problem (fig. 2), as the MM of the TV3-117 aircraft engine.

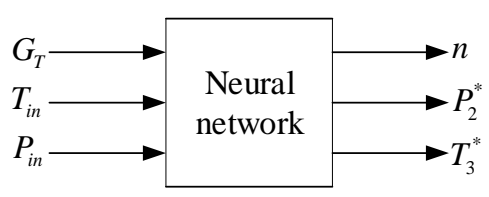

Figure 2 - Neural network model of the aircraft engine TV3-117

The solution of the problem of information recovery using the neural network model of the aircraft engine TV3-117 is decomposed into two subtasks: the task of identifying MM; task of information recovery.

Consider the task of restoring information using neural networks. The perceptron having the structure of 3-6-3 was chosen as the neural network, and the gradient method described in $[7,8]$ was used as the learning algorithm.

Let's analyze the computational costs of the neural network algorithm for the implementation of MM of the engine TV3-117 based on the microprocessor controller Raspberry Pi NanoPi M1 Plus and the neurochip Intel Neural Compute Stick 2. Their technical characteristics are given in table 1 . Table 1 shows that microcontrollers have the various clock frequencies, and multiply and divide operations are performed by them at different time intervals.

The time to access memory when reading / writing $T_{T A M}$ is calculated by the formula: 


$$
T_{T A M}=T_{B A T}+T_{D B T}+T_{B C T} ;
$$

where $T_{B A T}$ - bus address readiness time; $T_{D B T}-$ data bus readiness time; $T_{B C T}$-bus control time.

According to (1), we have:

$$
T_{\text {TAM }}=0.7519+0.7519+0.7519=2.2557 \mathrm{~ns} \text {. }
$$

The amount of memory required for a neural network in the RAM is calculated by the formula:

$$
V_{n n}=U\left(\sum_{i=1}^{3} N_{i}+N_{n n}+\sum_{i=1}^{2} N_{i} N_{i+1}\right)
$$

where $N_{i}$ - number of neurons in the $i$-th layer of the neural network; $N_{n n}$ - number of layers of the neural network; $\sum_{i=1}^{2} N_{i} N_{i+1}-$ number of weighing coefficients of the neural network; $U$ - number of digits when recording a displacement of a neuron (4 bytes).

Table 1 - Technical characteristics of microcontrollers

\begin{tabular}{|l|c|c|}
\hline \multicolumn{1}{|c|}{ Parameter } & $\begin{array}{c}\text { Raspberry Pi } \\
\text { NanoPi } \\
\text { M1 Plus } \\
\text { (processor - } \\
\text { Allwinner H3) }\end{array}$ & $\begin{array}{c}\text { Intel Neural } \\
\text { Compute Stick 2 } \\
\text { (processor - Intel } \\
\text { Atom Z3735F) }\end{array}$ \\
\hline Clock frequency & $1.2 \mathrm{GHz}$ & $1.33 \mathrm{GHz}$ \\
\hline $\begin{array}{l}\text { Maximum addi- } \\
\text { tion command } \\
\text { execution time }\end{array}$ & $0.833 \mathrm{~ns}$ & $0.7519 \mathrm{~ns}$ \\
\hline $\begin{array}{l}\text { Maximum execu- } \\
\text { tion time of the } \\
\text { multiplication } \\
\text { instruction }\end{array}$ & $8.33 \mathrm{~ns}$ & $0.7519 \mathrm{~ns}$ \\
\hline $\begin{array}{l}\text { Maximum execu- } \\
\text { tion time of the } \\
\text { division com- } \\
\text { mand }\end{array}$ & $16.67 \mathrm{~ns}$ & $0.7519 \mathrm{~ns}$ \\
\hline Digit (reg / data) & $32 / 64$ & $32 / 64$ \\
\hline Internal RAM & $1 \mathrm{~Gb}$ & $2 \mathrm{~Gb}$ \\
\hline
\end{tabular}

Then for a neural network having a structure (3-6-3), according to (2) we obtain:

$$
V_{n n}=4 \cdot((3+6+3)+3+(3 \cdot 6+6 \cdot 3))=204 \text { bytes. }
$$

During the work of the neural network, a number of mathematical (addition, multiplication, division) and logical (comparison) operations are performed. Herewith we calculate the weighted sum of inputs of the neuron, to which the offset is added. The obtained result is fed to the activation function of the neuron. As the last one in this case, a rational sigmoid is chosen: $z=f(x)$, calculated from the formula $[9,10]$ :

$$
z=\frac{x}{|x|+c}
$$

where $c$ - is the steepness of the sigmoid function (in calculations it was assumed $c=1$ ).
In this case, if neuroprocessor Intel Neural Compute Stick 2 neuron activation functions are implemented hardware, then on the Raspberry Pi NanoPi M1 Plus microcontroller they are performed programmatically. For a rational sigmoid (3) we obtain 2 operations: addition, division. In total, during the operation of the neural network, the following number of operations will be performed:

$$
\begin{gathered}
O S=N_{1}+\sum_{i=1}^{2} N_{i} N_{i+1}+\sum_{i=1}^{3} N_{i} ; \\
O U=N_{1}+\sum_{i=1}^{2} N_{i} N_{i+1}+\sum_{i=1}^{3} N_{i} ; \\
T_{f}=\sum_{i=1}^{3} N_{i} ;
\end{gathered}
$$

where $O S$ - number of addition operations; $O U-$ number of multiplication operations; $T_{f}$ - number of activation functions; $N_{i}$ - number of neurons in the $i$-th layer of the neural network. Then for the above structure of the neural network according to (4)-(6), we have:

$$
\begin{gathered}
O S=3+(3 \cdot 6+6 \cdot 3)+(3+6+3)=51 \\
O U=3+(3 \cdot 6+6 \cdot 3)+(3+6+3)=51 \\
T_{f}=9
\end{gathered}
$$

Assuming that all operations in the Intel Neural Compute Stick 2 microcontroller are performed in 1 cycle, including the activation function of the neuron, and also taking into account the bit rate, memory access speed and the parallelism of the algorithm, we have the total number of operations:

$$
O_{\text {Intel }}=\frac{51}{2}+\frac{51}{2}+\frac{3}{2}+\frac{6}{2}+\frac{3}{2}=57 .
$$

For the Raspberry Pi NanoPi M1 Plus microcontroller, the execution time of all operations (based on the sampling time of the memory data) can be calculated as

$T_{\text {Raspberry }}=O_{d} \cdot t_{d}+O S \cdot t_{p}+O U \cdot t_{m}+T_{f} \cdot t_{p}+V_{n n} \cdot t_{m e m} ;(7)$

where $t_{d}$ - the execution time of the division command; $t_{p}$ - runtime of the addition command; $t_{m}-$ runtime of the multiplication command; $t_{m e m}-$ the time it takes to sample data from memory. Then, according to (7), for Raspberry Pi NanoPi M1 Plus we obtain:

$$
\begin{aligned}
T_{\text {Raspberry }}=9 & \cdot 16.67+51 \cdot 0.833+51 \cdot 8.33+9 \cdot 0.833 \\
& +204 \cdot 0.833=794.772 \mathrm{~ns} .
\end{aligned}
$$

Given the different bit rates of the processor (32 bits) and operands (64 bits), the calculation time will be doubled:

$$
T_{\text {Raspberry }}=794.772 \cdot 2=1589.544 \mathrm{~ns} .
$$

For the Intel Neural Compute Stick 2 neuroprocessor, this time will be:

$$
T_{\text {Intel }}=57 \cdot 0.7519+204 \cdot 0.7519=196.246 \mathrm{~ns} .
$$


This shows that the specialized Intel Neural Compute Stick 2 processor performs neural network implementation 8 times faster than the Raspberry Pi NanoPi M1 Plus based compiler.

The results of the comparative analysis of the neural network method with the analytical (piecewise-linear) model of the aircraft engine TV3-117, as well as the polynomial regression model implemented on the basis of the least squares method of polynomial (ninth order), are given in table 2 .

Table 2 - Comparative analysis of different methods for solving the problem of parameters identification of aircraft engine TV3-117

\begin{tabular}{|c|c|c|c|c|c|}
\hline \multirow{2}{*}{ Models } & \multirow{2}{*}{$\begin{array}{c}\text { Calculation time, ns } \\
\text { Piece linear model }\end{array}$} & $\begin{array}{c}|c| \\
\text { Calculation error, } \%\end{array}$ \\
\cline { 3 - 6 } & bytes & $n$ & $P_{2}$ & $T_{3}$ \\
\hline Polynomial model & 2551.20 & 4777 & 3.677 & 2.829 & 6.266 \\
\hline Neural network model & 2943.70 & 843 & 1.118 & 1.515 & 2.539 \\
\hline
\end{tabular}

The data given in table 2 obtained by comparing the actual data of flight tests, with the data calculated for the above engine models and correspond to the change of its operation modes. Analysis of table 2 shows that the TV3-117 neural network model of the engine more effectively solves the problem of identifying its parameters: the maximum identification error did not exceed $0.762 \%$, which is 8.6 times less than the maximum error of the piecewise linear model and 3.7 times less than the maximum error of the polynomial model TV3-117 engine. Thus, the resulting neural network model can be effectively used as a part of BMDS to restore information in case of sensor failures.

An alternative approach to information recovery is the use of an auto-associative neural network (AANN) for these purposes, which has the property of compressing and then restoring information.

Known works [11, 12], which show the possibility of using AANN to restore the measured information on the thermogasdynamic parameters of aircraft engines. At the same time, in these works there are no methods of their construction and recommendations on the choice of the structure and algorithms of learning AANN.

The paper studies the features of formalization and solving the problem of information recovery in case of failures of the sensors of the engine TB3-117 using the AANN and on-board implementation of the corresponding algorithms. We will consider the following task: it is required to build an AANN that provides control and recovery of information (in case of failures) about the technical state of the TB3-117 aircraft engine in the presence of five standard sensors of thermogasdynamic parameters $n, G_{T}, P_{2}, T_{3}$.

Fig. 3 shows the architecture of the auto-associative neural network consisting of 3 layers. In this case, the AANN performs a mirror image of the input data vector to itself. Information is compressed in a hidden layer of the neural network, called the "eagle"; information is restored in the output layer. The principal possibility of using compressive mapping is the basis of the principal component method.

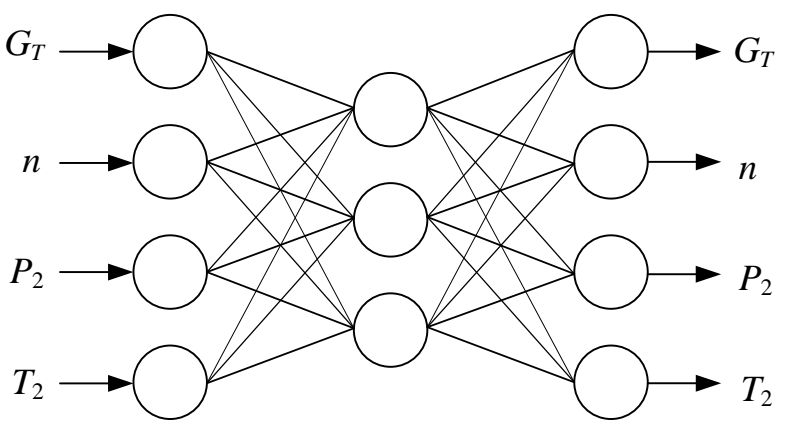

Figure 3 - Architecture of AANN

Fig. 4 shows a graph of the addiction of information recovery error by the network when one of the sensors (in this case, rotation speed sensor $n$ ) fails on the number of neurons in the throat of the AANN, where the relative size of the throat - the ratio of the number of neurons in the throat to the number of input / output neurons - is plotted on the $x$-axis (4 neurons). As can be seen from fig. 4 , the optimal size of the throat in this case is equal to 0.8 , i.e. the number of neurons in the throat (hidden layer of AANN) should be three.

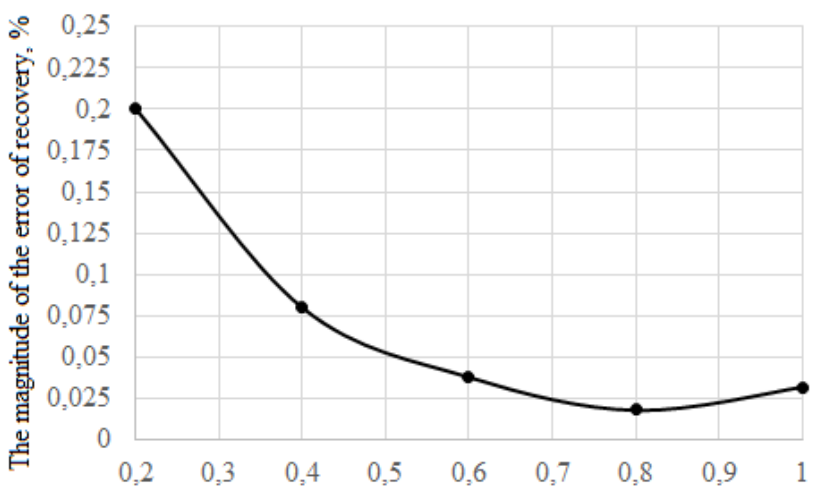

The ratio of the number of neurons in the "throat" to the number of input neurons

Figure 4 - Selection of the optimal structure of AANN

The data for training of AANN were obtained during the flight tests of the TV3-117 aircraft engine in a wide range of changes in its operation modes.

Along with the issue of choosing the AANN structure, an important step is the stage of information recovery from the results of the functioning of this neural network. 
In this paper, we use the approach proposed in [11] and depicted as a functional diagram in fig. 5.

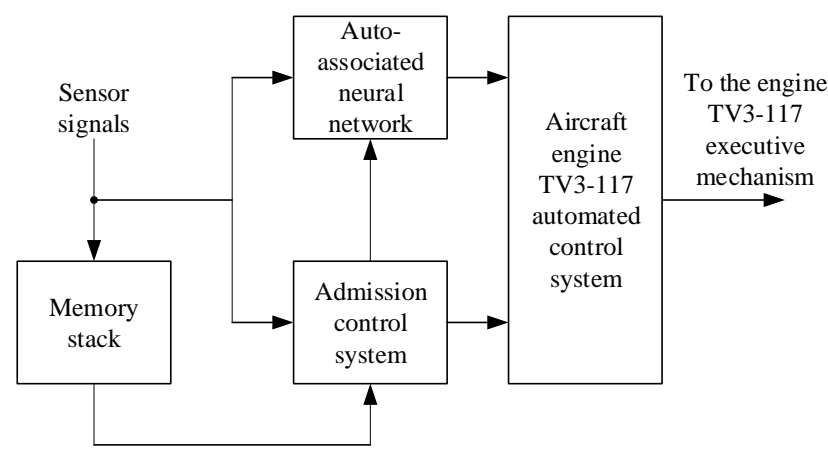

Figure 5 - Functional diagram of information recovery based on AANN

The results of information recovery of AANN in case of $P_{2}$ sensor failure are shown in table 3 .

Table 3 - Results of information recovery of AANN in case of one sensor failure

\begin{tabular}{|c|c|c|c|c|}
\hline \multirow{2}{*}{$\begin{array}{c}\text { The structure of the } \\
\text { AANN }\end{array}$} & \multicolumn{4}{|c|}{$\begin{array}{c}\text { Error recovery engine } \\
\text { parameters, \% }\end{array}$} \\
\cline { 2 - 5 } & $G_{T}$ & $n$ & $P_{2}$ & $T_{3}$ \\
\hline $4-3-4$ & 0.31 & 0.28 & 0.39 & 0.31 \\
\hline
\end{tabular}

In case of failure of other sensors, the recovery error does not exceed the values given in table 3 .

Analysis of the obtained results shows the high efficiency of the application of AANN in the process of information recovery. The results of data recovery in the case of double (multiple) failures of the sensors $P_{2}$ and $T_{3}$ are given in table 4 .

Analysis of the results given in table 4 shows that, despite the fact that the accuracy of information recovery in the case of double sensor failures deteriorates, the use of AANN ensures a satisfactory quality of information recovery, i.e., maintaining the operability of the measuring channels of the automatic control system of the engine TB3-117.

Table 4 - Results of information recovery of AANN in case of erative (double) failures of sensors

\begin{tabular}{|c|c|c|c|c|}
\hline \multirow{2}{*}{$\begin{array}{c}\text { The structure of the } \\
\text { AANN }\end{array}$} & \multicolumn{4}{|c|}{$\begin{array}{c}\text { Error recovery engine } \\
\text { parameters, \% }\end{array}$} \\
\cline { 2 - 5 } & $G_{T}$ & $n$ & $P_{2}$ & $T_{3}$ \\
\hline $4-3-4$ & 0.52 & 0.43 & 0.49 & 0.54 \\
\hline
\end{tabular}

We will analyze the required computational costs required to implement the neural network model of the engine based on the Raspberry Pi NanoPi M1 Plus microprocessor controller and the Intel Neural Compute Stick 2 neurochip (see table 1). The memory access time (read / write) is calculated similarly to (1). The memory size of RAM required for calculations using the neural network is calculated from (2):

$$
V_{n n}=4 \cdot((4+3+4)+3+(4 \cdot 3+3 \cdot 4))=152 \text { bytes. }
$$

In the process of calculating the outputs of the neural network, the following number of operations calculated on the basis of (4)-(6) will be performed:

$$
\begin{gathered}
O S=3+(4 \cdot 3+3 \cdot 4)+(4+3+4)=38 \\
O U=3+(4 \cdot 3+3 \cdot 4)+(4+3+4)=38 \\
T_{f}=7
\end{gathered}
$$

Considering that the operands are 32 bit, and the Intel Neural Compute Stick 2 processor is 64, and also taking into account that all operations are performed in 1 clock cycle, including the calculation of the neuron activation function (rational sigmoid), to perform the algorithm, you need to divide the number of operations:

$$
O_{\text {Intel }}=\frac{38}{2}+\frac{38}{2}+\frac{4}{2}+\frac{3}{2}+\frac{4}{2}=43,5 \text {. }
$$

For the Raspberry Pi NanoPi M1 Plus microcontroller, the execution time for all operations based on (7) will be:

$$
T_{\text {Raspberry }}=7 \cdot 16.67+43.5 \cdot 0.833+43.5 \cdot 8.33+
$$
$+7 \cdot 0.833+152 \cdot 0.833=647.728 \mathrm{~ns}$.

Considering the processor's bit depth (32 bits) and the bit width of operands (64 bits), the execution time will double:

$$
T_{\text {Raspberry }}=647.728 \cdot 2=1295.456 \mathrm{~ns} \text {. }
$$

For the Intel Neural Compute Stick 2 neuroprocessor, this time will be:

$T_{\text {Intel }}=43.5 \cdot 0.7519+152 \cdot 0.7519=146.996 \mathrm{~ns}$.

It follows that the specialized microcontroller performs the implementation of a neural network 8.8 times faster than an onboard computer based on the Raspberry Pi NanoPi M1 Plus.

Thus, the use of AANN in BMDS for data recovery allows ensuring the fault tolerance of the measuring channels of the control system of aircraft engine TV3117.

It is known that diagnostics consists in successively solving of two tasks: identifying the condition of TV3117 aircraft engine at each time point using parameters measured by the sensors (this task includes the task of recovering information if one of the sensors fails, solved in this work) and classifying its technical condition i.e. determination of the compliance of the engine condition with one of the classes (normal, faulty due to the failure of the $i$-th unit, operational, etc.) $[5,13,14]$. Taking into account the specific features of the TV3-117 aircraft engine, as a complex technical system with substantially non-linear characteristics, both of these tasks are effectively solved with the use of the mathematical apparatus of neural networks due to their number of indisputable advantages:

- they are able to solve problems poorly formalized by traditional mathematical methods, including control and diagnostics of the technical state of the engine TV3117 and the classification of its informationidentification features by classes of functional states;

- the solution of these tasks is possible in real time 
due to the high speed of the neural network, which is especially important for the onboard system;

- given the diversity of connections in the neural network, its reliable work is possible even after damage some of them;

- in the process of its work, the neural network is able to learn itself in accordance with the variable parameters in the process of operation of the engine.

Creation of an on-board system for monitoring and diagnosing the technical state of the engine on the basis of neural network technologies, the structural-logic scheme of which is shown in fig. 6 , includes the following steps:

- identification of systems and units, and aircraft engine TV3-117, i.e. the creation of a neural network (which includes the choice of its type and architecture), the input values of which are the functional parameters of the engine, recorded by the sensors, and the output the parameters that determine its condition, with the possibility self-training and correction of their parameters in the process of exploitation of a particular unit;

- creation of a training sample for the neural network on the basis of statistical information on the functional parameters of the engine in all modes of operation and the most likely failures of operation experience (for already operated engines) or bench test results (for those engines being developed or upgraded);
- training of the neural network using the training sample;

- verification of the adequacy and correctness of the created and trained neural network by modeling the operating modes and failures of engines not included in the training sample;

- hardware implementation of the developed neural network in electronic circuits, integrated into the system of automatic control of the engine.

Neural network control and diagnostics of the technical state of the engine is the network's neural expert system (NNES) [5], the main distinguishing features of which are:

- availability of a neural network knowledge base formed by neural network modules that solve a wide range of tasks for monitoring and diagnosing the technical condition of TV3-117 aircraft engine: data conversion and interaction with other programs, statistical processing and analysis of data, monitoring of gasdynamic processes, monitoring the technical condition of engine sensors, monitoring engine operating conditions, identification of the engine technical condition, engine technical condition monitoring, technical condition diagnostics of the engine, predicting the technical condition of the engine, debugging the parameters of the engine, restoring information in case of a sensor failure;

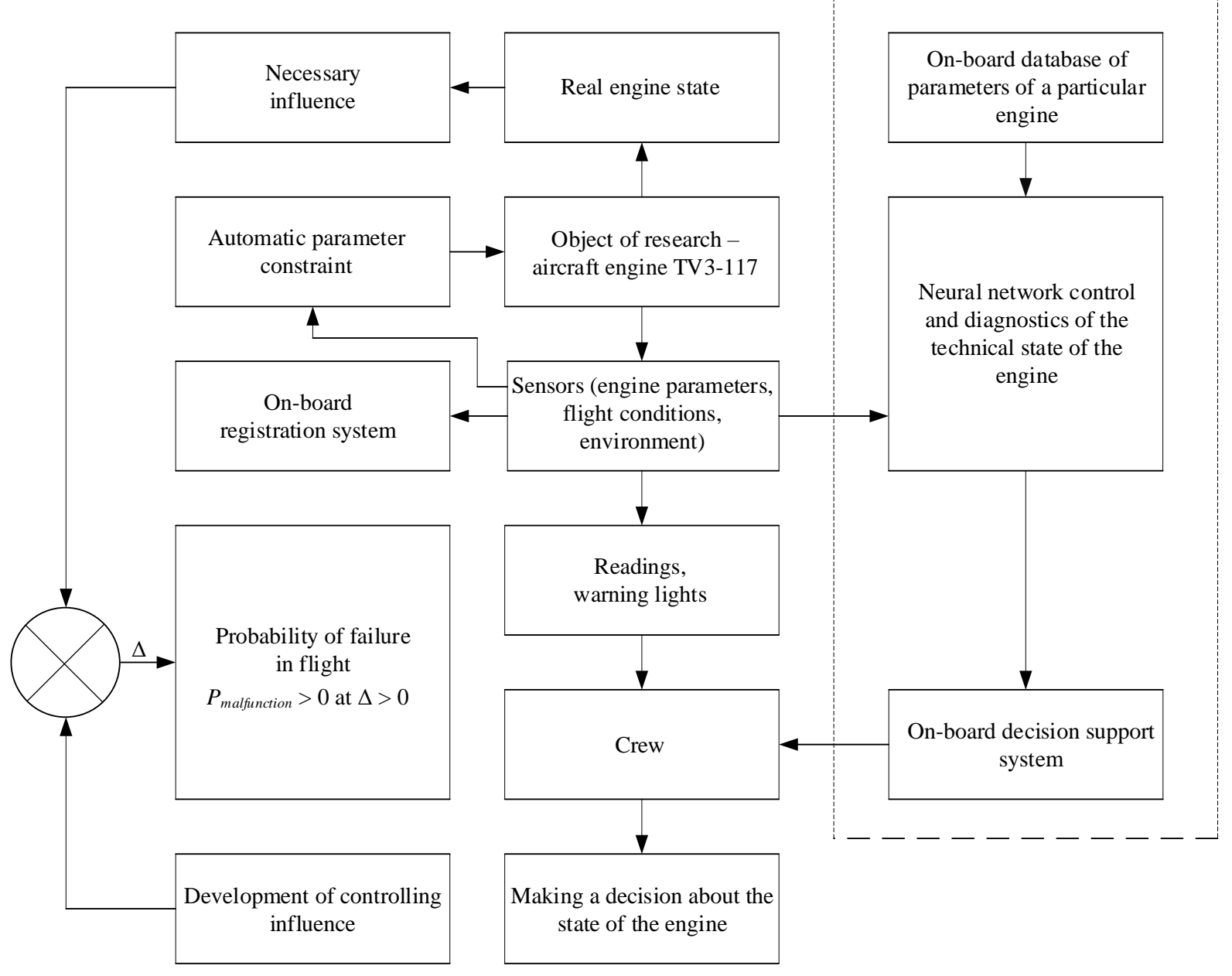

Figure 6 - Structural-logical scheme of the control and diagnostics system of aircraft engine TV3-117 technical condition in flight modes 
- availability of a base of fuzzy rules and a knowledge base of precedents that increase the efficiency and quality of solving problems for monitoring and diagnosing the technical state of the TV3-117 aircraft engine;

- availability of network components, which allows real-time exchange of test records of serial engines and accumulate experience in their operation, while simultaneously highlighting and complementing knowledge in the knowledge base.

The core of NNES, coordinating the process of intermodular interaction, as well as supporting the interface with the user, is a monitor control program that provides an internal "scenario of work" with system blocks and an interface with various simulation environments.

The inference engine is composed of three main components: a solver, a scheduler, and a decision module. The solver forms the problem and implements its solution. The scheduler plans the necessary computing resources to solve the problem. The decision module forms the decision rule on the basis of which the NNES decides on the technical condition of the aircraft engine. Knowledge Base NNES is a combination of diverse knowledge: expert and neural network knowledge base. The expert knowledge base takes into account the quantitative component of the process of monitoring and diagnosing an aircraft engine, and the neural network knowledge base - its qualitative (informal) part.

The management process (coordination) of diverse knowledge bases is carried out by the knowledge management system.

NNES interacts with the engine through sensors, input controllers and a data processing subsystem. Communication with network resources within the industry or a single enterprise can be carried out via a modem and the Internet.

A special feature of NNES is its modularity and openness, which allows adding new monitoring and diagnostic algorithms to it.

CONCLUSIONS. The main advantage of the use of neural networks in the framework of BMDS is the possibility of training and further training in real time, taking into account the individual characteristics of engine TV3-117.

The features of the implementation of the neural network data recovery algorithms in case of a failure of the standard sensors in the BMDS structure of the aircraft engine TV3-117 are considered. Shown, that:

- implementation of the neural network multimode model of engine TV3-117 reduces the error in calculating its thermogasdynamic parameters by 3.7 ...8.6 times as compared with the piecewise linear model of the aircraft engine TV3-117 and by 1,5...3,5 times compared with a polynomial model of the 9th order; at the same time, by reducing the number of multiplication operations, the gain is ensured compared to the piecewise linear and polynomial models using the Raspberry Pi NanoPi M1 Plus calculator, respectively: by the computation time by 13 and 15 times; the required memory capacity is by 8.5 and 1.5 times (when using the Intel
Neural Compute Stick 2 neuroprocessor, the time to calculate the neural network is additionally reduced by 2 times);

- information recovery in case of sensor failure using an auto-associative neural network provides a data recovery error of no more than $0.38 \%$ in case of single failures and no more than $0.54 \%$ in the case of double failures; at the same time, the calculation time for 1 data recovery cycle using five standard sensors is 1295.456 ns for the Raspberry Pi NanoPi M1 Plus calculator and $146.996 \mathrm{~ns}$ for the specialized neural processor Intel Neural Compute Stick 2, which meets the on-board implementation requirements of the TV3-117 aircraft engine BMDS [5].

\section{REFERENCES}

1. Ntantis E. L. Diagnostic Methods for an Aircraft Engine Performance. Journal of Engineering Science and Technology. 2015. Rev. 8 (4). P. 64-72.

2. Gernakov S., Vasilev V. and Musluhov I. Onboard algorithms for monitoring parameters of gas turbine engines based on neural network technology. Scientific Bulletin of the Moscow State Technical University of Civil Aviation. 2009. No. 1 (30). P. 61-74.

3. Kiakojoori S. and Khorasani K. Dynamic neural networks for gas turbine engine degradation prediction, health monitoring and prognosis. Neural Computing \& Applications. 2016. Vol. 27, no. 8. P. 2151-2192.

4. Shevchenko I., Tertyshnyi V. and Koval S. Designing a model of a decision support system based on a multi-aspect factographic search. Eastern-European Journal of Enterprise Technologies. 2017. Vol. 4, iss. 2 (88). P. 20-26. Doi: https://doi.org/ 10.15587/17294061.2017.108569

5. Shmelov Y., Vladov S., Klimova Y. and Kirukhina M. Expert system for identification of the technical state of the aircraft engine TV3-117 in flight modes. System Analysis \& Intelligent Computing : IEEE First International Conference on System Analysis \& Intelligent Computing (SAIC) (Kiev, 08-12 October 2018). P. 77-82.

6. Heberlig E. S. and Larson B. A. Party Fundraising, Descriptive Representation, and the Battle for Majority Control: Shifting Leadership Appointment Strategies in the U.S. House of Representatives. Social Science Quarterly. 2007. Vol. 88, iss. 2. P. 404-421.

7. Vladov S. and Klimova Y. Application of the adaptive training method of the neural network for diagnostics of the Mi-8MTV helicopter engine. Information Technologies: Science, Technology, Technology, Education, Health (MicroCAD-2018), (Kharkiv, 16-18 May 2018). Part 1. P. 14.

8. Shmelev Y., Vladov S., Boyko S., Klimova Y. and Vishnevskiy S. Diagnostics of the state of the Mi8MTV helicopter engine using neural networks. Bulletin of the Khmelnytsky National University. 2018. No. 3. P. 165-170.

9. Elfwing S., Uchibe E. and Doya K. Sigmoidweighted linear units for neural network function approximation in reinforcement learning. Neural Networks. 2018. Vol. 107. P. 3-11. 
10. Yamanashi Y., Umeda K. and Yoshikawa N. Pseudo Sigmoid Function Generator for a Superconductive Neural Network. IEEE Transactions on Applied Superconductivity. 2013. Vol. 23, iss. 3. P. 17010041701004. Doi: 10.1109/TASC.2012.2228531

11. Valeev S., Vasilev V. and Ilyasov B. Faulttolerant control systems of complex dynamic objects using artificial neural networks. Neurocomputers: development, application. 2000. No. 1. P. 32-35.

12. Meril U. Detection of failures of GTE sensors due to analytical redundancy. Aerospace Engineering. 2004. No. 6. P. 28-41.

13. Shmelov Y., Vladov S., Kryshan O., Gvozdik S. and Chyzhova L. Research of classification method of TV3-117 engine ratings operations based on neural network technologies. Innovative technologies and scientific solutions for industries. 2018. No. 4 (6). P. 93-102.

\section{БОРТОВОЙ МЕТОД ВОССТАНОВЛЕНИЯ ИНФОРМАЦИИ ПРИ ОТКАЗЕ ОДНОГО ИЗ ДАТЧИКОВ АВИАЦИОННОГО ДВИГАТЕЛЯ ТВЗ-117 НА ОСНОВЕ НЕЙРОСЕТЕВЫХ ТЕХНОЛОГИЙ}

\section{С. И. Владов, К. Г. Котляров, С. А. Грибанова, О. В. Гусарова, Л. И. Чижова}

Кременчугский летный колледж Харьковского национального университета внутренних дел

ул. Победы, 17/6, г. Кременчуг, 39605, Украина. E-mail: ser26101968@ gmail.com

Решена одна из ключевых проблем, возникающих на борту летательного аппарата, заключается в выявлении параметрических отказов датчиков, а именно, ухудшения их характеристик путем разработки бортового метода восстановления информации (когда один из датчиков авиационного двигателя ТВ3-117 выходит из строя) на основе нейросетевых технологий. Это обеспечивает отказостойкость измерительных каналов системы управления авиационного двигателя ТВ3-117. Для реализации поставленных задач применены методы теории вероятности и математической статистики, нейроинформатики, теории информационных систем и обработки данных. В работе использованы две архитектуры нейронной сети - типа перцептрон и автоассоциативная нейронная сеть со свойством сжатия и дальнейшего восстановления информации. Разработан метод определения оптимальной структуры нейронной сети, заключающийся в установлении архитектуры нейронной сети, выборе оптимального алгоритма поиска веса нейронов и обучении нейронной сети, анализе эффективности разных алгоритмов обучения нейронной сети, определении структуры нейронной сети, заключающийся в нахождении минимальной ошибки обучения нейронной сети в зависимости от количества нейронов в спрятанном слое, а также в анализе эффективности результатов. Показано, что реализация многорежимной нейросетевой модели авиационного двигателя ТВ3-117 обеспечивает уменьшение ошибки при расчете его термогазодинамических параметров в 3,7...8,6 раз по сравнению с кусочно-линейной моделью авиационного двигателя ТВ3-117 и в 1,5 і 3,5 раза по сравнению с полиномиальной моделью девятого порядку. Восстановление информации при отказе датчика с помощью автоассоциативной нейронной сети дает ошибку восстановления данных не больше 0,38 \% в случае единичных отказов і не больше $0,54 \%$ - при двойных отказах. Разработаны алгоритмы нейронной сети для восстановления информации при выходе из строя стандартных датчиков как части бортовой системы мониторинга и диагностики технического состояния авиационного двигателя ТВ3-117 на основе использования автоассоциативных нейронных сетей. Их применение позволяет восстановить потерянную информацию с реальной точностью в режиме реального времени и повысить качество и эффективность решений при оценке технического состояния авиационного двигателя TV3-117.

Ключевые слова: авиационный двигатель, нейронная сеть, микропроцессор, нейропроцессор, восстановление.

Стаття надійшла 04.12.2019.. 